\title{
Poliosis and neurofibromatosis type 1: Is it a true association?
}

\section{Selma El Kadiri, Hanane Baybay, Rhizlane Chaoui, Zakia Douhi, Sara Elloudi, Fatima Zahra Mernissi}

Department of Dermatology and Venereology, University Hospital Hassan II, Fez, Morocco

Corresponding author: Dr. Selma El Kadiri, E-mail: elkadiri-s@hotmail.com

Sir,

A 42-year-old-man presented with axillary freckling, multiple café-au-lait macules and neurofibromas on the scalp, face, trunk and extremities. In addition, he had a patch of white hair on the vertex area overlying a scalp neurofibroma. He was diagnosed with poliosis circumscripta associated with neurofibromatosis 1 .

Poliosis circumscripta or "white forelock", defined as a localized patch of white hair in a group of hair follicles, can be secondary to multiple causes: hereditary or acquired [1]. We report the case in a patient followed for neurofibromatosis type 1 who developed a poliosis circumscripta over a scalp neurofibroma.

A 32-year-old patient presented with a patch of white hair on the scalp evolving for 11 years, with multiple skin lesions gradually increasing in number and size. Dermatological examination revealed the presence of multiple café-au-lait macules, axillary lentigines and multiple neurofibromas of the trunk and extremities. In addition, he had a Z-shaped plaque of the vertex area evolving since the age of 21 overlying a palpable neurofibroma (Fig. 1). Ophthalmological examination revealed the presence of Lisch nodules and the patient's physical and mental development was normal. The patient was diagnosed with $\mathrm{NFl}$ in association with poliosis circumscripta.

The association of poliosis and neurofibromatosis type I has been reported in 7 patients [2]. In children, poliosis may be the sign of several genetic syndromes including piebaldism, tuberous sclerosis and Waardenburg syndrome. While poliosis occurring on a neurofibroma is rarely reported in the literature and has been described

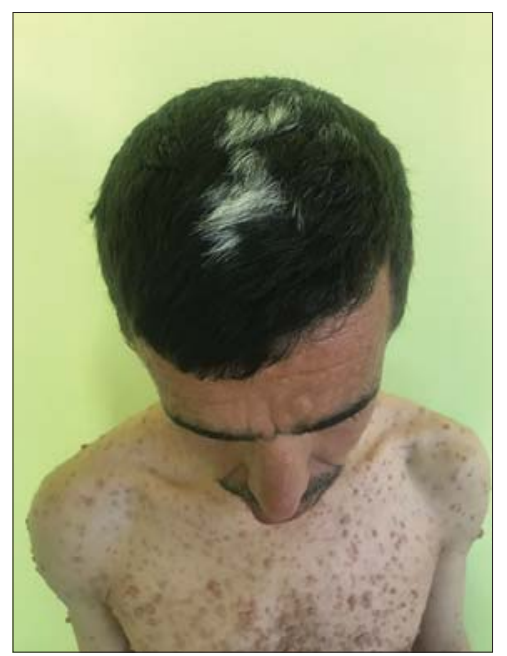

Figure 1: Poliosis circumscripta on the vertex area.

in 4 patients [3]. The etiology of this association has not yet been elucidated. Depigmentation of the scalp hairs with an underlying neurofibroma could be of an autoimmune response in which the $\mathrm{T}$ cells cytotoxic of the neurofibroma attack the melanocytes in the hair follicles consequently leading to their destruction [4].

The feature of our case is the location of poliosis in the vertex and the Z-shap aspect which has not been reported before.

The frequency of poliosis in patients with neurofibromatosis type 1 remains unknown. Further studies are needed to determine the exact mechanism of this association.

\section{Consent}

The examination of the patient was conducted according to the Declaration of Helsinki principles.

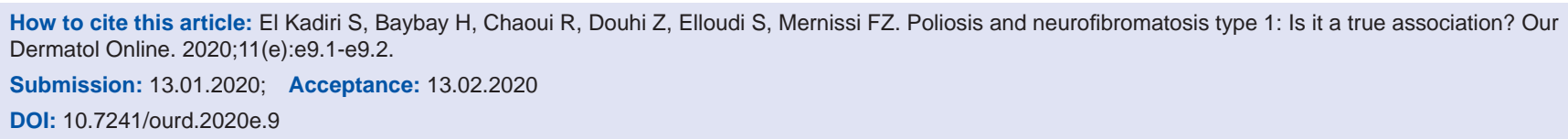




\section{www.odermatol.com}

The authors certify that they have obtained all appropriate patient consent forms. In the form the patient(s) has/have given his/her/ their consent for his/her/their images and other clinical information to be reported in the journal. The patients understand that their names and initials will not be published and due efforts will be made to conceal their identity, but anonymity cannot be guaranteed.

\section{REFERENCES}

1. Sleiman R, Kurban M, Succaria F, Abbas O. Poliosis circumscripta: overview and underlying causes. J Am Acad Dermatol. 2013; 69:625-33.
2. Lee JH, Cho KH, Kim JA, Moon SE. Poliosis circumscripta associated with neurofibroma. J Dermatol. 2005;32:446-9.

3. Sandoval-Tress C, Nava-Jiménez G. Poliosis circumscripta associated with neurofibromatosis Australas J Dermatol. 2008;49:167-8.

4. Neri I, Liberati G, Piraccini BM. Poliosis and neurofibromatosis type 1: two familiar cases and review of the literature. Skin Appendage Disord. 2017;3:219-21.

Copyright by Selma El Kadiri, et al. This is an open-access article distributed under the terms of the Creative Commons Attribution License, which permits unrestricted use, distribution, and reproduction in any medium, provided the original author and source are credited. Source of Support: Nil, Conflict of Interest: None declared. 